\title{
Trace Metal Concentrations in the Liquid Phase of Phosphate Rock-Treated Soils
}

\author{
J. CSILLAG, A. LUKÁCS, E. OSZTOICS, P. CSATHÓ and GY. BACZÓ \\ Research Institute for Soil Science and Agricultural Chemistry (RISSAC) of the \\ Hungarian Academy of Sciences, Budapest
}

\section{Introduction}

The application of slowly dissolving, reactive, basic phosphate rocks - which are favourable alternative crop P-sources in the case of acidic soils - may cause environmental hazards, as (similarly to commercial P fertilizers), depending on their origin they may contain potentially toxic contaminants (SAUERBECK, 1992; SOLER SOlER \& SOLER ROVIRA, 1996; VAN KAUWENBERGH, 1997; OSZTOICS et al., 2005). Special attention has been focussed on cadmium, which has serious human toxicological concerns. P fertilizers produced from sedimentary phosphate rocks having a high Cd content are considered as a major source of Cd contamination in agricultural soils (HAMON et al., 1998; MERRINGTON et al., 2002; BOLAN et al., 2003). In the Rothamsted field experiment Cd uptake of plants increased due to the long-term application of superphosphate fertilizers (NICHOLSON et al., 1994). In Hungary, however, the intensive P fertilization in the 1970s-1980s was carried out with superphosphate made from Russian magmatic Kola phosphate rock practically free of Cd. Therefore, Hungarian agricultural soils have not been polluted with Cd due to the application of P fertilizers (KÁDÁR, 1991, 2003; DEBRECZENI et al., 2000).

An indicator of the environmentally hazardous accumulation of potentially toxic elements may be their appearance and increased concentration in the soil solution. Few studies are available on the impact of $\mathrm{P}$ fertilizer (including phosphate rock) application on toxic element concentrations in the soil solution (TAYLOR \& PerCiVAL, 2001; Csillag et al., 2005). The objectives of this study were

- to determine heavy metal and other toxic element concentrations in the liquid phase of two acidic soils at increasing phosphate rock doses applied in a pot experiment, and

- to evaluate the potential contaminating, and - simultaneously - the pH elevating and toxic metal immobilizing effects of the applied phosphate rocks.

Correspondence to: Julianna CSILLAG, Research Institute for Soil Science and Agricultural Chemistry (RISSAC) of the Hungarian Academy of Sciences, H-1022 Budapest, Herman Ottó út 15. Hungary. E-mail: lukacs@rissac.hu 


\section{Materials and Methods}

The bulk samples for the pot experiment were collected from the ploughed layer of an acidic sandy soil and a slightly acidic clay loam soil (from Nyírlugos and Ragály, resp., Hungary) (Table 1).

Table 1

Main chemical and physical properties of the studied soils

\begin{tabular}{|c|c|c|c|c|c|c|}
\hline \multirow{2}{*}{ Soil } & \multicolumn{2}{|c|}{$\mathrm{pH}$} & \multirow{2}{*}{$\begin{array}{c}\text { Organic } \\
\text { matter, } \\
\end{array}$} & $\begin{array}{c}\text { Cation ex- } \\
\text { change capacity } \\
\text { cmol } \cdot \mathrm{kg}^{-1}\end{array}$ & $\begin{array}{c}\text { Clay+silt } \\
<0.02\end{array}$ & $\begin{array}{c}\text { Clay } \\
<0.002\end{array}$ \\
\cline { 2 - 3 } & $\mathrm{H}_{2} \mathrm{O}$ & $\mathrm{KCl}$ & $\%$ & & \multicolumn{2}{c|}{$\mathrm{mm}, \%$} \\
\hline $\begin{array}{c}\text { Acidic sandy soil } \\
\text { (Nyírlugos) } \\
\begin{array}{c}\text { Slightly acidic clay } \\
\text { loam soil (Ragály) }\end{array}\end{array}$ & 5.0 & 3.8 & 0.6 & 3.0 & 5.0 & 2.2 \\
\hline
\end{tabular}

Table 2

Phosphate rock (PR) doses applied in the experiment

\begin{tabular}{|c|c|c|c|}
\hline \multirow{2}{*}{ Sign } & \multirow{2}{*}{$\mathrm{mg} \mathrm{P}_{2} \mathrm{O}_{5} \cdot \mathrm{kg}^{-1}$ soil } & \multicolumn{2}{|c|}{$\mathrm{g} \mathrm{PR} \cdot \mathrm{kg}^{-1}$ soil } \\
\cline { 3 - 4 } & & Senegal & Morocco \\
\hline \multirow{2}{*}{$\mathrm{d} 1$} & 1400 & 4.2 & 5.4 \\
$\mathrm{~d} 2$ & 1600 & 4.9 & 6.1 \\
$\mathrm{~d} 3$ & 3200 & 9.7 & 12.3 \\
$\mathrm{~d} 4$ & 6400 & 19.4 & 24.5 \\
\hline
\end{tabular}

Increasing doses of two sedimentary phosphate rocks with high Cd content (Senegal and Morocco), particle size $<160 \mu \mathrm{m}$, were added and mixed into the airdried soil samples at the beginning of the experiment. The detailed description of the pot experiment and phosphate rocks' properties is published by OszToICs et al. (2006). Phosphorus doses applied on the non-cropped, control soils and used for the soil solution studies are shown in Table 2 .

The moisture level of the control soils, similarly to the cropped samples, was initially adjusted to $\sim 60 \%$ of field capacity. They were periodically watered with deionised water to maintain this moisture level for two months (the vegetation period of the plant in the pot trial).

In order to obtain soil solution, at the end of the pot experiment the control samples were air dried, 1-1 kg soil was placed in air tight plastic vessels, then they were rewetted to field capacity with deionised water (to $26.5 \%$ and $28.3 \%$ gravimetric water content of Nyírlugos and Ragály soil, resp.). After one week incubation, during which the wet soil samples were homogenized three times, the soil solution was extracted by 1 hour centrifugation. A rotor speed (5000-5500 rpm) corresponding to $-1500 \mathrm{kPa}$ (the suction power exerted by the plant at the conventional 
wilting point) was applied, so the separated solution could be regarded as "plant available" (CSILLAG et al., 1999).

"Total" element contents in the untreated soils and in the applied phosphate rock samples were determined in their 1:50 extracts made with concentrated $\mathrm{HNO}_{3}$ $+\mathrm{H}_{2} \mathrm{O}_{2}$ solution by applying microwave wet digestion in teflon bomb. As, $\mathrm{Ba}, \mathrm{Cd}$, $\mathrm{Co}, \mathrm{Cr}, \mathrm{Cu}, \mathrm{Hg}, \mathrm{Mn}, \mathrm{Mo}, \mathrm{Ni}, \mathrm{Pb}, \mathrm{Sr}$ and $\mathrm{Zn}$ concentrations in the soil solutions and in the extracts were determined by ICP spectrometry. The total P content of the phosphate rock samples was also measured with ICP in the extract of the acid digestion. The $10 \% \mathrm{HCl}$ soluble carbonate content of the phosphate rock samples was determined in Scheibler calcimeter, and expressed as $\mathrm{CaCO}_{3} \%$.

\section{Results and Discussion}

Trace metal and other potentially toxic element contents of the initial (untreated) soils and the applied phosphate rock samples

The potentially toxic element contents of the untreated sandy soil - determined by acid digestion before the set-up of the pot trial - were several times lower than those of the clay loam soil (Table 3). In the sandy soil they were much lower than the background concentrations given in the corresponding Hungarian standard: e.g. the Cd content was more than one order of magnitude less than the national background threshold level. In the clay loam soil $\mathrm{Cr}$ and $\mathrm{Ni}$ contents were somewhat higher than the background concentrations and the Ba content considerably exceeded it (Table 3). Cd content in the clay loam soil was several times higher $(0.2$ $\left.\mathrm{mg} \cdot \mathrm{kg}^{-1}\right)$ than in the sandy soil $\left(0.04 \mathrm{mg} \cdot \mathrm{kg}^{-1}\right)$ and both values were in the lower part of/or below the $0.1-0.5 \mathrm{mg}$ "total" $\mathrm{Cd} \cdot \mathrm{kg}^{-1}$ range measured in unpolluted Hungarian field soils in the 2001-2003 period (MÁTHÉ-GÁSPÁR et al., 2004).

In both phosphate rock samples the $\mathrm{Cr}$ and especially $\mathrm{Cd}$ contents considerably exceeded the previous strict Hungarian limit values for P fertilizers (Table 3). (Since May 1, 2004, when Hungary became an EU member state, no threshold values have been specified for toxic elements in case of fertilizers distributed as "EU fertilizer”, in accordance with the 2003/2003/EK decree of the European Parliament and Council.)

Concentrations of trace metals and other potentially toxic elements in the soil solution of the initial (untreated) soils

Concentrations of the elements in the liquid phase of the untreated sandy soil were, with the exception of Co, lower than or near to the allowed tolerable concentrations in subsurface waters, but most were higher than the corresponding background concentrations (Table 4). In case of the clay loam soil Ba and Ni concentrations exceeded the allowed threshold values. 


\begin{tabular}{|c|c|c|c|c|c|c|}
\hline \multirow{14}{*}{ 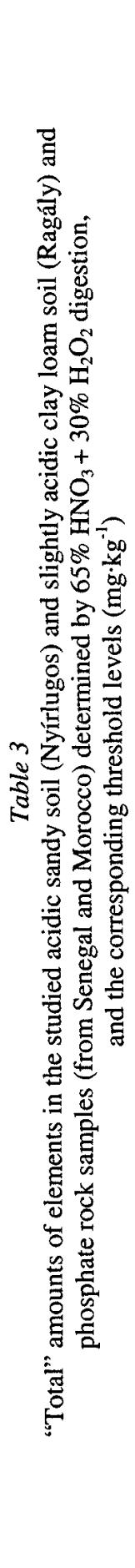 } & $\mathbb{N}$ & 으요 & 8 & 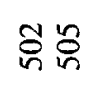 & & \\
\hline & 占 & $=g$ & & ถู오 & & \\
\hline & 2 & $\tilde{b} \widetilde{N}$ & $\approx$ & $\vec{\forall} \vec{i}$ & $\S$ & \\
\hline & $\bar{z}$ & $\stackrel{i}{i}$ & $\approx$ & ga & 무 & \\
\hline & $\stackrel{8}{\Sigma}$ & $\bar{\nabla} \overrightarrow{\mathrm{V}}$ & $n$ & $\bar{i}=$ & & \\
\hline & $\Sigma$ & $\stackrel{ }{\sim}$ & & 동 & & \\
\hline & 告 & $\bar{\nabla} \vec{\nabla}$ & $\stackrel{n}{0}$ & $\overline{\bar{\nabla}} \overline{\mathrm{V}}$ & - & \\
\hline & 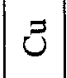 & $\stackrel{\infty}{i} \underset{\sim}{\sim}$ & $\stackrel{m}{ }$ & $\infty \ddot{i}$ & & \\
\hline & $u$ & $m \underset{m}{m}$ & m & $g \frac{n}{2}$ & $\stackrel{8}{2}$ & \\
\hline & 8 & $\stackrel{+}{m}=$ & $\cong$ & iீ? & & \\
\hline & $\bar{u}$ & ¿̊口 & $\tilde{a}$ & $\exists \bar{n}$ & 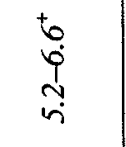 & \\
\hline & $\ddot{\varphi}$ & $\tilde{ก}$ & $\stackrel{\circ}{2}$ & $\therefore$ in & & \\
\hline & $\dot{\psi}$ & İ & $?$ & $\stackrel{\ominus}{-i}$ & $\Omega$ & \\
\hline & 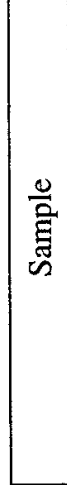 & 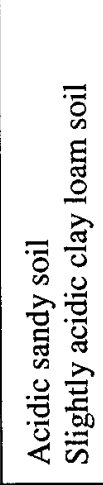 & 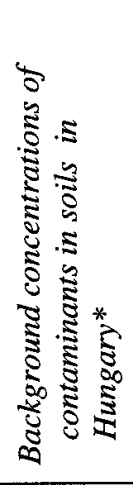 & 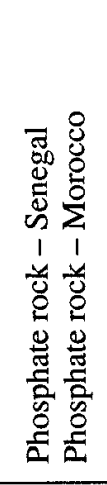 & 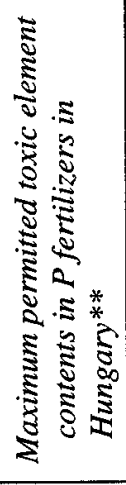 & \\
\hline
\end{tabular}




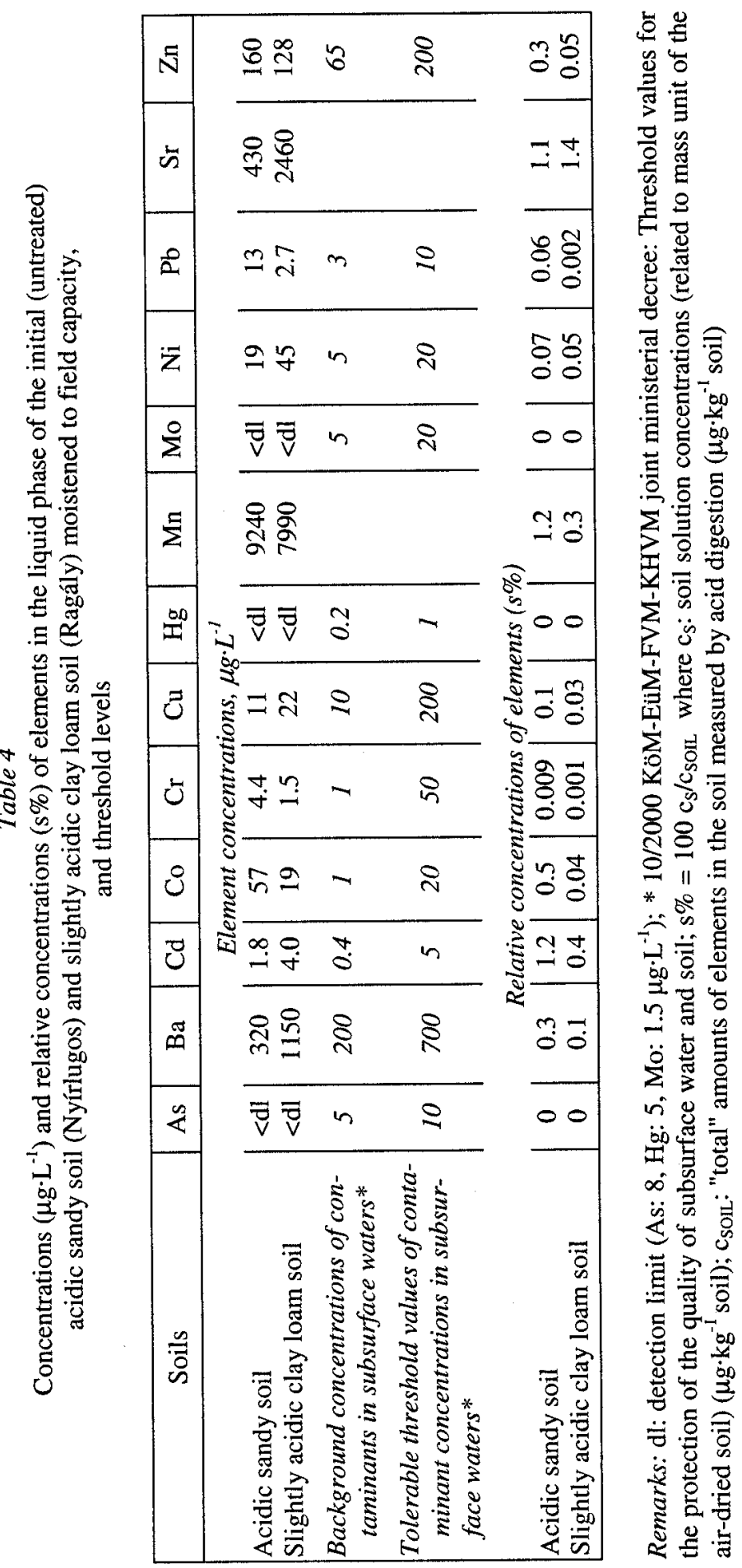


Although element contents determined by acid digestion were higher in the clay loam soil than in the sandy soil (Table 3), this tendency was true only for Ba, Cd, $\mathrm{Cu}, \mathrm{Ni}$ and $\mathrm{Sr}$ concentrations in the soil solution (Table 4). When soil solution concentrations $\left(\mathrm{C}_{\mathrm{S}}\right)$ were expressed as a percentage of the "total" amounts in the soil measured by acid digestion ( $\mathrm{c}_{\text {SoIL }}$ ), the relative metal concentrations in the soil solution ( $\left.\mathrm{s} \%=100 \mathrm{cs} / \mathrm{c}_{\text {SOIL }}\right)$ were, with the exception of $\mathrm{Sr}$, higher in the colloid-poor sandy soil (Table 4) as was expected in a soil retaining metals weakly. (CS was related to mass unit of the air-dried soil: $\mu \mathrm{g} \cdot \mathrm{kg}^{-1}=\left(\mu \mathrm{g} \cdot \mathrm{L}^{-1} \times\right.$ gravimetric water content of the soil) $\cdot 100^{-1}$.)

Effect of phosphate rock application rates on soil $\mathrm{pH}$ and metal concentrations in the soil solution

As compared to agricultural practice the applied phosphate rock doses were extremely high. The d3 dose (3200 mg $\mathrm{P}_{2} \mathrm{O}_{5} \cdot \mathrm{kg}^{-1}$ soil) (Table 2), for example, was more than 100 times greater than the application rate commonly used on fields under intensive fertilization ( $40 \mathrm{~kg} \mathrm{P} \cdot \mathrm{ha}^{-1}=90 \mathrm{~kg} \mathrm{P}_{2} \mathrm{O}_{5} \cdot \mathrm{ha}^{-1}=30 \mathrm{mg} \mathrm{P}_{2} \mathrm{O}_{5} \cdot \mathrm{kg}^{-1}$ soil).

Addition of basic phosphate rocks decreased the acidity of both soils. The $\mathrm{pH}(\mathrm{KCl})$ values measured in the control samples $\left(0 \mathrm{mg} \mathrm{P}_{2} \mathrm{O}_{5} \cdot \mathrm{kg}^{-1}\right.$ soil $)$ of the sandy and clay loam soils at the end of the pot experiment were 3.7 and 4.5, resp., lower than the $\mathrm{pH}(\mathrm{KCl})$ values of the phosphate rock-treated soils (Fig. 1). In the $\mathrm{d} 1$ to $\mathrm{d} 4$ range of increasing phosphate rock doses the $\mathrm{pH}(\mathrm{KCl})$ increased by 0.4 and 0.1 (Senegal) and 0.8 and 0.3 (Morocco) units for the sandy soil and the clay loam soil, respectively (Fig. 1). In the case of the $\mathrm{d} 4$ (Morocco) treatment the $\mathrm{pH}$ of the two soils became identical; the initially more acidic sandy soil reached the $\mathrm{pH}$ of the clay loam soil. The somewhat more basic Morocco phosphate rock $(\mathrm{pH}=8.1$, $\mathrm{CaCO}_{3}$ content $=14 \%$ ) had a more stronger $\mathrm{pH}$-increasing effect than the Senegal phosphate rock $\left(\mathrm{pH}=7.9, \mathrm{CaCO}_{3}\right.$ content $\left.=4 \%\right)$.

Metal release to the soil solution in the phosphate rock-treated soils at increasing phosphate rock rates was characterized by relative metal concentrations:

$$
s \%=\frac{100 c_{s}}{c_{\text {SOIL }}+c_{P R}}
$$

where: $\mathrm{c}_{\mathrm{s}}$ : soil solution concentrations (related to mass unit of air-dried soil) $\left(\mu \mathrm{g} \cdot \mathrm{kg}^{-1}\right.$

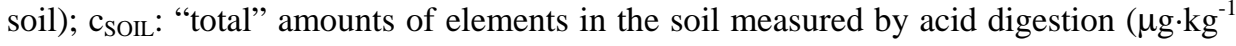
soil); $\mathrm{C}_{\mathrm{PR}}$ : metal amounts carried into the soils with the phosphate rocks; (for d2: see Table 5).

After the two month long experiment during which the soils were subjected to repeated drying-rewetting periods, the relative metal concentrations (s\%) decreased with increasing phosphate rock doses in the sandy soil (Fig. 1) due to the $\mathrm{pH}$ elevating and cation immobilizing effects of phosphate rocks (BOLAN et al., 2003). The relative concentrations were generally lower in treatments with the more basic Morocco phosphate rock than with the Senegal phosphate rock. Generally s\% values 

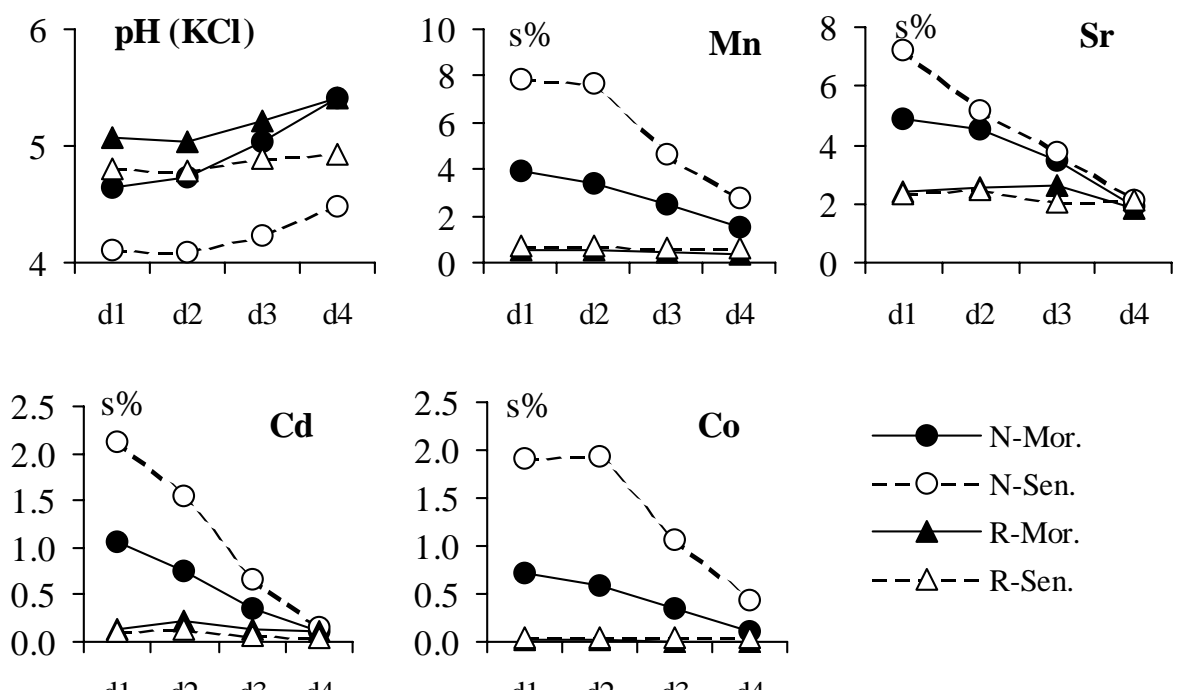

d1 $\quad$ d2 $\quad$ d3 $\quad$ d4

d1 $\quad$ d2 $\quad$ d3 $\quad$ d4
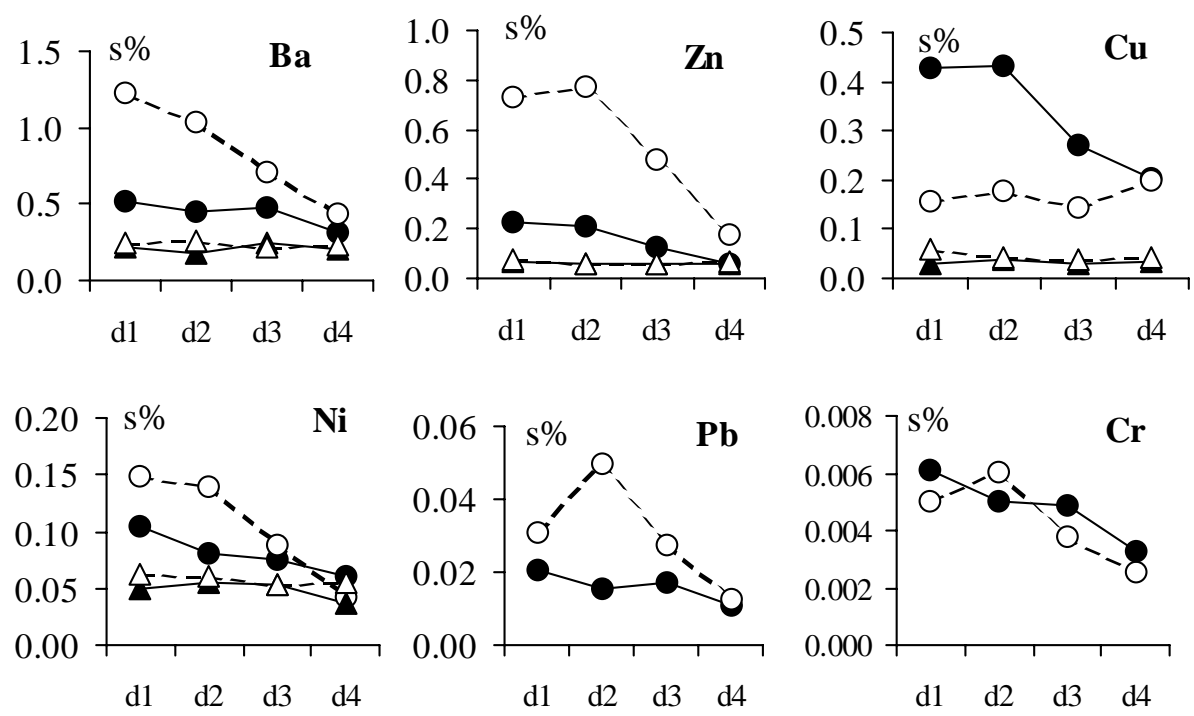

Fig. 1

Change in soil $\mathrm{pH}(\mathrm{KCl})$ and relative amounts (s\%) of potentially toxic metals entering the soil solution in the case of increasing phosphate rock doses.

Phosphate rock doses: d1-d4: 1400, 1600, 3200 and $6400 \mathrm{mg} \mathrm{P}_{2} \mathrm{O}_{5} \cdot \mathrm{kg}^{-1}$ soil, resp.

N: Acidic sandy soil (Nyírlugos); R: Slightly acidic clay loam soil (Ragály);

Mor.: Phosphate rock from Morocco; Sen.: Phosphate rock from Senegal; 
Table 5

Amounts of the studied metals $\left(\mu \mathrm{g} \cdot \mathrm{kg}^{-1}\right.$ soil) carried into the soil with the $\mathrm{d} 2$ phosphate rock dose (1600 $\mathrm{mg}_{2} \mathrm{O}_{5} \cdot \mathrm{kg}^{-1}$ soil)

\begin{tabular}{|l|c|c|r|r|r|r|r|r|r|c|}
\hline $\begin{array}{c}\text { Phosphate } \\
\text { rock }\end{array}$ & $\mathrm{Ba}$ & $\mathrm{Cd}$ & $\mathrm{Co}$ & $\mathrm{Cr}$ & $\mathrm{Cu}$ & $\mathrm{Mn}$ & $\mathrm{Ni}$ & $\mathrm{Pb}$ & $\mathrm{Sr}$ & $\mathrm{Zn}$ \\
\hline $\begin{array}{l}\text { Senegal } \\
\text { Morocco }\end{array}$ & 380 & 550 & 27 & 580 & 330 & 850 & 240 & 20 & 3090 & 2440 \\
\hline
\end{tabular}

were not high in the sandy soil: e.g. the max. amount of $\mathrm{Cd}$ that entered the soil solution was only $2.1 \%$ of the total Cd present in the soil + phosphate rock system (41 $\mu \mathrm{g} \cdot \mathrm{L}^{-1}$ at the $\mathrm{d} 1$ dose of the Senegal phosphate rock applied to the sandy soil).

In the clay loam soil $\mathrm{s} \%$ values, characterizing the mobility of metals, were much lower than in the more acidic light textured Nyírlugos soil (Fig. 1). With increasing phosphate rock doses they remained practically constant. The two applied phosphate rocks' effect on the s\% value was similar in the clay loam soil.

Comparing s\% of the metals, $\mathrm{Mn}, \mathrm{Sr}$ and to a smaller extent $\mathrm{Cd}$ and Co were the most, while $\mathrm{Pb}$ and $\mathrm{Cr}$ the least mobile elements in this experiment (Fig. 1). In the d1 (1400 mg $\mathrm{P}_{2} \mathrm{O}_{5} \cdot \mathrm{kg}^{-1}$ soil) treatment with Senegal phosphate rock, for example, s\% values of $\mathrm{Mn}, \mathrm{Sr}, \mathrm{Cd}$ and Co were $7.9 \%, 7.2 \%, 2.1 \%$ and $1.9 \%$, resp., in case of the sandy soil. The corresponding values for $\mathrm{Ba}, \mathrm{Zn}, \mathrm{Cu}$ and Ni were lower: $1.2 \%$, $0.7 \%, 0.16 \%$ and $0.15 \%$, resp. These values for $\mathrm{Pb}$ and $\mathrm{Cr}$ were very low, $0.03 \%$ and $0.005 \%$, resp., in the sandy soil and not measurable in the clay loam soil, which indicates that these metals were completely bound. The concentrations of the anion forming As and Mo were below the detection limit in the liquid phase of both acidic soils even in case of the highest phosphate rock dose.

\section{Conclusions}

The phosphate rocks used in the pot experiment contained rather high amounts of potentially toxic metals, therefore the environmental hazard when applying them to the soil was considerable. Relative metal concentrations in the liquid phase of the acidic sandy soil (Nyírlugos), however, generally decreased with increasing phosphate rock rates. This means that under the conditions of the present pot experiment soil solution concentrations were influenced less by the amount of contaminants carried into the soil with the increasing phosphate rock doses than by the immobilizing effect of phosphate rocks. In the slightly acidic clay loam soil (Ragály) the relative metal concentrations were low and did not change with the increase in phosphate rock rates. This indicates that the two opposing effects (increased input of metals versus phosphate rocks' immobilizing effect) were compensated in this soil. 
It was concluded that in the experimental time frame the environmental risk (i.e. the accumulation of toxic metals in the soil solution), depending on the soil properties, decreased or did not change with increasing phosphate rock rate.

\section{Summary}

Concentrations of potentially toxic elements were determined in the soil solution of two soils (acidic sandy and slightly acidic clay loam) treated with phosphate rocks having high $\mathrm{Cd}$ content in a pot experiment. Relative concentrations characterizing the mobility of metals (expressed as soil solution concentrations in percentage of their "total" amounts in the phosphate rock-treated soil) decreased with increasing phosphate rock rates in the sandy soil. $\mathrm{Mn} \cong \mathrm{Sr}>\mathrm{Cd} \cong \mathrm{Co}$ were the most, while $\mathrm{Pb}$ and $\mathrm{Cr}$ the least mobile elements. The relative concentrations in the clay loam soil were much lower than in the sandy soil and they practically remained constant with increasing phosphate rock rates. It was concluded that in the experimental time frame the environmental risk did not increase with the increase of phosphate rock rate.

The present study was supported by the Hungarian National Scientific Research Fund (OTKA) under grant No. T 038046.

Key words: soil solution, trace metal, phosphate rock

\section{References}

Bolan, N. S., Adriano, D. C. \& NAIDU, R., 2003. Role of phosphorus in (im)mobilization and bioavailability of heavy metals in the soil-plant system. Rev. Environ. Contam. Toxicol. 177. 1-44.

CsillaG, J. et al., 1999. Extraction of soil solution for environmental analysis. Intern. J. Environ. Anal. Chem. 74. 305-324.

CSILlAG, J. et al., 2005. Effect of phosphate rock and acid treatment on toxic element concentrations of the soil solution in a laboratory experiment. (In Hungarian) Agrokémia és Talajtan. 54. 325-340.

DeBreCZENI, K. et al., 2000. Effect of increasing fertilizer doses on the soluble P, Cd, $\mathrm{Pb}$, and Cr content of soils. Commun. Soil Sci. Plant Anal. 31. 1825-1835.

HAMON, R. E. et al., 1998. Long-term changes in cadmium bioavailability in soil. Environ. Sci. Technol. 32. 3699-3703.

KÁDÁR, I., 1991. Heavy metal content in soils and crops in Hungary. (Ed.: LiGETINECHAY, E.) (In Hungarian) KTM, MTA TAKI, Budapest.

KÁDÁR, I., 2003. Effect of fertilizer application on the fertility of a calcareous chernozem soil (Nagyhörcsök). In: Correlations between Fertilization, Soil Acidification and Liming on Soils of the National Long-Term Fertilization Trials (OMTK). 
(Eds.: BlASKÓ, L. \& ZsigrAI, Gy.) (In Hungarian) 55-68. $2^{\text {nd }}$ ed. Karcag-Keszthely.

MÁthÉ-GÁspáR, G. et al., 2004. After-effect of cadmium load on the soil and plants on a brown forest soil. (In Hungarian) Agrokémia és Talajtan. 53. 143-154.

Merrington, G., L. et al., 2002. Agricultural Pollution. Environmental Problems and Practical Solutions. Spon Press. London.

NiChOlson, F. A., JonEs, K. C. \& JOHnSTON, A. E., 1994. Effect of phosphate fertilizers and atmospheric deposition on long-term changes in the cadmium content of soils and crops. Environ. Sci. Technol. 28. 2170-2175.

OszTOICS, E. et al., 2005. Analysis of the agronomic efficiency of rock phosphate in a pot experiment. I. Laboratory evaluation of rock phosphates. (In Hungarian) Agrokémia és Talajtan. 54. 341-358.

OszTOICS, E. et al., 2006. Effect of five phosphate rocks on red clover (Trifolium pratense L.) yield in pot trial. Commun. Soil Sci. Plant Anal. 37. (In press).

SAUERBECK., D., 1992. Conditions controlling the bioavailability of trace elements and heavy metals derived from phosphate fertilizers in soils. In: Proc. $4^{\text {th }}$ Int. IMPHOS Conf. Phosphorus, Life and Environment. From Research to Application. 419448. World Phosphate Institute. Casablanca.

Soler Soler, J. \& Soler RovirA, J., 1996. Cadmium in inorganic fertilizers. In: Fertilizers and Environment. (Ed.: Rodriguez-BARrueCO, C.). Developments in Plant and Soil Sciences. 66. 541-545. Kluwer Academic Publishers. Dordrecht.

TAYlor, M. D. \& Percival, H. J., 2001. Cadmium in soil solutions from a transect of soils away from a fertiliser bin. Environ. Pollut. 113. 35-40.

VAN KaUwenbergh, S. J., 1997. Cadmium and other minor elements in world resources of phosphate rock. The Fertiliser Society. Proc. No. 400. London.

10/2000. (VI. 2.) 2000. Joint KöM-EüM-FVM-KHVM ministerial decree: Threshold values for the protection of the quality of subsurface water and soil. (In Hungarian) Magyar Közlöny. 53. 3156-3167.

50/2003. (V. 9.), 2003. FVM ministerial decree: Authorization, storage, distribution and utilization of fertilizers and other soil amendments. (In Hungarian) Magyar Közlöny. 49. 4342-4347..

2003/2003/EK., 2003. Joint decree of EP and EU Council on fertilizers (13. 10. 2003). Official Journal of the European Union (21. 11. 2003). L 304. 